\title{
RECOVERABILITY OF ECONOMIC LOSS ARISING FROM DEFECTIVE BUILDINGS IN MALAYSIA: BALANCING THE JUST INTERESTS*
}

\author{
Mohd Altaf Hussain Ahangar**
}

\begin{abstract}
The judicial approach to the recoverability of economic loss arising from defective buildings has been uncertain globally. Malaysia has been no exception to this process. Until recently, it either allowed or disallowed such claim irrespective of the status of the defendant and public interest. However, in two reported cases of 2006, namely Majlis Perbandaran Ampang Jaya v Steven Phoa Cheng Loon and Lim Teck Kong v Dr. Abdul Hamid Abdul Rashid, the court came out with two different judgments although the plaintiffs in both cases claimed defective building economic loss. The varying decisions took into consideration the status of the defendants and public interest rather than the nature of claim. Analysis of both judgments suggests that the Malaysian judiciary is playing a constructive role in the evolution of a just society in Malaysia.
\end{abstract}

A revised version of a paper presented at the $4^{\text {th }}$ Asian Law Institute Conference, Jakarta on 24-25 May 2007.

Professor, Ahmad Ibrahim Kulliyyah of Laws, International Islamic University Malaysia. 


\section{INTRODUCTION}

The initial judicial approach to the recognition of pure economic loss has not been positive because it raised the specter of opening the floodgates litigation due to the potential for indeterminate liability. ${ }^{1}$ Such approach was irrespective of the fact whether the claim resulted from negligent misrepresentation; negligent performance of a service; relational economic loss and defective products or building structures. However, the scenario changed with the recognition of a claim based on negligent misstatement in Hedley Byrne. ${ }^{2}$ From that moment onwards, the courts at global level especially in England, America, Canada, New Zealand, Australia, Singapore and Malaysia have oscillated at different times in recognition and non- recognition of such claims. However, the recent judicial approach in Malaysia makes us realize that the oscillating process has come to end and the allowance or non-allowance of this claim in future depends on the factual position of each case and the main criterion for the court is whether it is just, fair and reasonable to hold the defendant liable.

An attempt is made in this article to critically analyze the recent judgments of Malaysia's Court of Appeal and Federal Court respectively in Lim Teck Kong v Dr. Abdul Hamid Abdul Rashid ${ }^{3}$ and Majlis Perbandaran Ampang Jaya v Steven Phoa Cheng Loon ${ }^{4}$ in order to identify the latest judicial responses to a claim for pure economic loss suffered on account of defective buildings in Malaysia. However, a brief reference to the judicial approach in relation to this claim in other jurisdictions, particularly, England is also made in order to add relevance to the discussion. The article concludes with the observation that the judgments of Malaysian courts in the above two cases is an indicator that the judiciary is making bold efforts to balance the just interests of the litigating parties in relation to economic loss suffered on account of defective buildings in Malaysia.

1 See Caltex Oil (Australia) Pty Ltd v The Dredge “Willemstad” (1976) 136 CLR 529 at 573-574.

$2 \quad$ Hedley Byrne \& Co. Ltd v Heller \& Partners Ltd [1964] AC 465.

3 Lim Teck Kong v Dr Abdul Hamid Abdul Rashid [2006] 3 MLJ 213.

$4 \quad$ Majlis Perbandaran Ampang Jaya v Steven Phoa Cheng Loon [2006] 2 MLJ 389. 


\section{AN OVERVIEW OF THE POSITION IN ENGLAND}

Donoghue v Stevenson ${ }^{5}$ was interpreted by writers as not allowing a claim based on pure economic loss resulting from negligent act or omission but this myth has been destroyed when the Court of Appeal in Dutton v Bognor Regis Urban District Council ${ }^{6}$ allowed damages in relation to a claim arising out of the defective construction of a building. In this case, the Court of Appeal observed that 'a local authority was liable to a building owner in respect of negligent inspection of inadequate foundations constructed by a builder, in the course of exercising its statutory powers to require compliance with building regulations.' ${ }^{7}$ This case was followed by Anns ${ }^{8}$ wherein the House of Lords almost on similar facts allowed the claim against the local authority. While laying down the two-tier test or what later on became known as Anns test, Lord Wilberforce stated that allowing such claim was 'necessary in order to avoid a present or imminent danger to the health or safety of the persons occupying it. ${ }^{9}$ In his view the plaintiff had suffered 'a material physical damage.' 10 The high watermark for allowing pure economic loss claim was achieved in Junior Books Ltd. ${ }^{11}$ wherein the House of Lords by a majority held that because of the close proximity between the parties, a duty of care was owed to the plaintiff. The key factor was that the plaintiff had nominated the defendants as subcontractors. Lord Roskill observed:

The proximity of relationship between the plaintiffs and the defendants was extremely close: 'almost as close a

\footnotetext{
$5 \quad$ Donoghue v Stevenson [1932] AC 562.

$6 \quad$ Dutton v Bognor Regis Urban District Council [1972] 1 QB 373.

$7 \quad$ Ibid. at p. 397-398.

$8 \quad$ Anns v Merton London Borough Council [1978] AC 728.

$9 \quad$ Ibid. at p. 760.

10 Ibid. at p. 759. New Zealand courts allowed such claims in Bowen v Paramount Builders (Hamilton) Ltd [1977] I NZLR 394 and Mount Albert Borough Council v Johnson [1979] 2 NZLR 234. Likewise, Canadian Supreme Court allowed such claims in City of Kamloops v Nielsen [1984] 2 SCR 2 and Central Trust Co v Rafuse [1986] 2 SCR 147.

$11 \quad$ Junior Books Ltd v Veitchi Ltd [1982] 3 All ER 201.
} 
commercial relationship... as it is possible to envisage a short of privity of contract. ${ }^{12}$

The decisions in Anns and Junior Books did not prove popular with the judiciary at the global level because the cases raised the question of whether it was right to allow the tort remedy to bypass limitations of liability and other protections built into the contractual structure. ${ }^{13}$ The first challenge came from the Australian High Court in Sutherland Shire Council ${ }^{14}$ wherein it was observed that a council is under a duty to take some action to prevent injury only if its antecedent acts have created or increased a risk of injury of that kind. But no duty was imposed and no private right of action was conferred on a purchaser of a building for damages in respect of damage, which the council would or might have prevented, by a careful exercise of its powers. Sutherland Shire Council was followed in England by D\&F Estates Ltd. ${ }^{15}$ In this case, Lord Bridge drew a distinction between a product, which causes personal injury or damage to property other than itself, for which liability in tort will follow from Donoghue and a product, which is dangerously defective where the defect is discovered before any such damage is caused. In the latter case, there was:

"No longer any room for the application of the Donoghue $v$ Stevenson principle. The chattel is now defective in quality, but is no longer dangerous. It may be valueless or it may be capable of economic repair. In either case the economic loss is recoverable in contract by a buyer or hirer of the chattel entitled to the benefit of a relevant warranty of quality, but is not recoverable in tort by a remote buyer or hirer of the chattel." 16

\footnotetext{
$12 \quad$ Ibid. at pp. 213-214.

13 In this case, it later transpired that the plaintiff had already settled a contractual claim against the main contractors, subject to agreed limitation of liability. See Atiyah, An Introduction to the Law of Contract [Oxford University Press, 5th Ed] at p. 383n.

$14 \quad$ Sutherland Shire Council v Heyman (1985) 60 ALR 1.

$15 \quad$ D \& F Estates Ltd $v$ Church Commissioners for England [1988] 2 All ER992.

$16 \quad$ Ibid. at p. 1006.
} 
The House of Lords reaffirmed $D$ \& F Estates in Murphy. ${ }^{17}$ In this case, while overruling Duttons and departing from Anns, the seven Lordships of the House of Lords observed that a local authority is not liable in negligence to a building owner or occupier for the cost of remedying a dangerous defect, which resulted from the negligence of the authority in not ensuring that the building was erected in accordance with the building regulations. The court apprehended 'an exceedingly wide field of claims involving something in the nature of a transmissible warranty of quality. ${ }^{18}$ Besides the court was unanimous in stating that any decision to impose a higher common law duty on builders and local authorities should be based on policy reasons and these policy reasons are the province of the Parliament and not the courts. ${ }^{19}$

Murphy still rules England in relation to a claim for pure economic loss suffered on account of defective building, although a claim for pure economic loss resulting from other factors has been allowed on the basis of the 'Categorization Approach' ${ }^{20}$ and the 'Open-ended Approach.'21

\section{POSITION IN MALAYSIA}

After the decision of Murphy, the Malaysian courts started dealing with claims for economic loss on account of defective buildings. Prior to Lim Teck Kong ${ }^{22}$ and Majlis Perbandaran Ampang Jaya, ${ }^{23}$ Malaysian courts at the High Court level followed Murphy faithfully in several cases. In the case of Kerajaan Malaysia $v$ Cheah Foong Chiew, ${ }^{24}$ the plaintiff claimed damages for the negligence of the defendants in supervising buildings constructed for the plaintiff. The damages were claimed by the plaintiff for the cost of repairing the

\footnotetext{
$17 \quad$ Murphy v Brentwood District Council [1990] 1 AC 398.

$18 \quad$ Ibid. at p. 469.

$19 \quad$ Ibid. at p. 457.

$20 \quad$ See White $v$ Jones [1995] 2 AC 207; Haris v Evans [1998] 1 WLR 1285;

Phelps v Hilligdon London Borough Council [2001] 2 AC 619.

$21 \quad$ Spring v Guardian Assurance Plc [1995] 2 AC 295.

22 Supran 3.

$23 \quad$ Supran 4.

$24 \quad$ Kerajaan Malaysia v Cheah Foong Chiew [1993] 2 MLJ 439.
} 
buildings to make them safe for occupation. One of the defendants, an assistant resident engineer, applied for striking out the claim, inter alia, on the ground of pure economic loss. While endorsing the rationale in Murphy and agreeing with the defendant, Wan Mohamed J observed that:

It was not reasonable for an employee including a skilled worker working under a person or a construction company to be held liable to the owner of a building for his negligence which resulted in the non-completion of the building but which did not cause injury to a person or to the property of another. ${ }^{25}$

This case was followed by Teh Khem On $v$ Yeoh \& Wu Development Sdn Bhd. ${ }^{26}$ In this case, the plaintiffs had purchased a double-storey link house from the developer. After the plaintiffs had taken possession of the house, they discovered that there were cracks on the walls and floor. The house had also tilted and was sinking. The plaintiffs brought a claim against the builder, the architect and the engineer. The court held the builder liable for breach of contract. In relation to the architect and the engineer, while analyzing the developments in England, New Zealand and Australia, it observed that:

The claims against the architect and the engineer relate solely to the defective condition of the house and as such the pure economic loss suffered on this account was not recoverable in negligence in the circumstances of the case. ${ }^{27}$

$25 \quad$ Ibid. at p. 441.

$26 \quad$ Teh Khem On $v$ Yeoh \& Wu Development Sdn Bhd [1995] 2 MLJ 663.

27 Ibid. at p. 677. The same approach was adopted by the High Court in Pilba Trading \& Agency $v$ South East Asia Insurance Bhd [1998] 2 MLJ 53 wherein the subject matter was not the house but the economic loss suffered on account of non-use of the damaged car for a period of fifty-nine days. 


\section{Engineer Cannot Escape Liability}

Some countries could not accept the absoluteness of the Murphy rule for all circumstances and for all times. The main challenge to Murphy came from the Australian High Court in the case of Bryan. ${ }^{28}$ In this case, a subsequent purchaser of a house brought an action against the builder for damage caused to the fabric of the house due to cracks in the walls and the floor resulting from defective footings. The Australian High Court, by a majority, held the builder liable for negligence. The court was of the view that a house could be used indefinitely and is likely to be the most significant investment that an owner, original or subsequent, will make during his lifetime. According to the court, these factors created sufficient proximity in the relationship between a subsequent purchaser and the builder. ${ }^{29}$

Almost simultaneously the Canadian Supreme Court was confronted with the problem in Winnipeg Condominium Corp No $36 .{ }^{30}$ In this case a developer had hired a builder to construct an apartment block as per the plans drawn by the architect. In the process, the builder employed a sub-contractor to fix the external cladding of the building. The cladding fell off and the plaintiff, a subsequent owner, incurred expenses in the repair. The plaintiff sued the builder, the sub-contractor and the architect to recover his expenses. The court held the defendants liable for the cost of repairs to make the building safe for occupation. Being critical of the House of Lords decision in D \& F Estates, ${ }^{31}$ the court observed that 'the unfortunate result of the reasoning in the case left subsequent purchasers with no remedy against contractors who put them at considerable risk by constructing buildings using sub-standard materials and workmanship. ${ }^{32}$ La Forest J further added:

"No adequate policy considerations exist to negate a contractor's duty in tort to subsequent purchasers of a building to take reasonable care in constructing the

$28 \quad$ Bryan v Maloney (1995) 128 ALR 163.

$29 \quad$ Ibid. at p. 171.

$30 \quad$ Winnipeg Condominium Corp No 36 v Bird Construction Co. (1995) $121 \operatorname{DLR}\left(4^{\text {th }}\right) 193$.

$31 \quad$ Ibid. at pp. 201-212.

$32 \quad$ Ibid. at pp. 205-206. 
building, and to ensure that the building does not contain defects that pose foreseeable and substantial danger to the health and safety of the occupants. ${ }^{33}$

The following year, the Privy Council on an appeal against the decision of the New Zealand Court of Appeal had to deal with a similar issue in Invercargill City Council. ${ }^{34}$ In this case, the plaintiff owner engaged a builder to construct a house. The city council approved the plans for the foundations. Subsequently, the foundations were found to be defective, and cracks appeared in the house. The plaintiff sued the city council for damages. While holding the defendants liable for the pure economic loss suffered by the plaintiff, the Privy Council was of the view:

"The New Zealand courts have a right to develop local
common law according to local policy considerations,
which included the demands of community standards to
impose a duty of care on local authorities and builders
to ensure compliance of bye-laws."35

Even the Singapore judiciary did not remain unaffected by the developments in Australia and New Zealand. In RSP Architects Planners \& Engineers $^{36}$ it had to deal with the issue. In this case, the plaintiff, a management corporation of a condominium, sued the developer for pure economic loss arising out of the faulty construction of the common property that had led to spalling of concrete in the ceilings of the car park and water ponding in the area surrounding the lifts. While allowing the plaintiff's claim on the basis of proximity, the Court of Appeal observed that 'the approach of the courts has been to examine a particular circumstance to determine whether there exists that degree of proximity between the plaintiff and the defendant as would give rise to a duty of care by the latter to the former with respect to the damage sustained by

\footnotetext{
$33 \quad$ Ibid. at p. 221.

$34 \quad$ Invercargill City Council v Hamlin [1996] 1 NZLR 513.

$35 \quad$ Ibid. at p. 521.

$36 \quad$ RSP Architects Planners \& Engineers v Ocean Front Pte Ltd [1996]

1 SLR 113.
} 
the former; such proximity was the determinant of the duty of care and also the scope of such duty. ${ }^{37}$ The court was further of the opinion that 'there were no policy considerations militating against the imposition of a duty of care in the case at hand. ${ }^{38}$

These decisions initially resulted in the Malaysian High Court ${ }^{39}$ (and later on the Court of Appeal) changing its adherence to the Murphy principle in Lim Teck Kong. ${ }^{40}$ In this case the plaintiffs owned a piece of land and hired an engineering firm to construct a double-storey bungalow. After moving into the house, the rear portion of the bungalow collapsed within about $3 \frac{1}{2}$ years due to a landslide and as a result, the bungalow became uninhabitable. The plaintiff sued inter alia the engineering firm and its proprietor. One of the defences raised by the defendants was the pure economic loss suffered by the plaintiff due to the house being a 'defective product.' The defendants were held liable by the High Court, Shah Alam. The Court of Appeal comprising of Mokhtar Sidin JCA; Haidar Mohd Noor JCA and Abdul Kadir Sulaiman JCA did not allow the appeal against the judgment. After going through the judicial process in relation to pure economic loss in England and other jurisdictions, Mokhtar Sidin JCA endorsed the following observations of James Foong J at High Court level:

The main objective behind non-allowance of the claim primarily is to avoid the creation of liability for an indeterminate amount for an indeterminate time to an indeterminate class. ${ }^{41}$....But this could be a misconception and an unallied fear ${ }^{42}$....The amount of damages so claimed is not an indeterminate amount. They are the expenses and costs involved in repairing,

Ibid. at pp. 141-142.

Ibid. at p. 142. RSP Architects Planners \& Engineers was reaffirmed by the Court of Appeal in RSP Architects Planners \& Engineers Raglan Squire \& Partners FE v Management Corporation Strata Title Plan No 1075 [1999] 2 SLR 449.

Dr. Abdul Hamid Abdul Rashid v Jurusan Malaysia Consultants [1997] 3 MLJ 546.

Supra $\mathrm{n} 3$.

Ibid. at p. 231.

Ibid. at p. 232. 
making good or replacing the defective product, or cost that may be involved in ensuring the defective product is of the condition that it should be in the first place. As for indeterminate time, it may be true that liability to a subsequent owner might be greater than the first owner but it can be 'limited by the element of reasonableness both in the requirement that the damage be foreseeable and in the content of the duty of care.' ${ }^{43}$ In respect of indeterminate class ... it is obviously foreseeable that loss will be sustained by whichever of the first or subsequent owners who happen to be the owner at the time when the inadequacy of the footing becomes manifest. ${ }^{44}$

After this extensive quotation from the High Court judgment, the learned judges of the Court of Appeal concluded:

In our view, the learned judge was within his right to award damages on pure economic loss. We have been too long in the shadow of the House of Lord's decisions of Murphy and D\& F Estates. We are of the view that it is time for us to move out of that shadow and move along with other Commonwealth countries where damages could be awarded on pure economic loss. In the media we have seen how consumers suffer due to shoddy and haphazard manner of the developers and contractors in putting up buildings with so many defects and, in most cases, delay. The legislature and the government are fully aware of this and for those reasons a special tribunal has been set up to cater for complaints in respect of houses. As such the courts should also play their part in this. ${ }^{45}$

The court was of further view that the losses suffered by the plaintiffs were not pure economic losses. The evidence shows that the

$43 \quad$ The learned judge took these words from Bryan v Maloney (1995) 128 ALR 163.

44 Ibid.

$45 \quad$ Supra $\mathrm{n} 3$ at p. 233. [Emphasis Supplied]. 
damages suffered by the plaintiffs were the loss of the bungalow, ${ }^{46}$ i.e., loss of property. With respect, this observation may not be correct as with this observation because it was due to the defect in the property on the basis of which the defendant was rightly defending the claim against himself. Had the house suffered damage due to collapsing of other property, then it could have been treated as damage to the property. Basically it was economic loss suffered on account of defective building. Generally such matters are to be settled under contract law but the element of 'just, fair and reasonable' as one of the requirements for duty of care in negligence justifies the judgment of the court.

\section{Non-Liability of Local Authority}

The 'just, fair and reasonable' element of duty of care was recently interpreted and applied by Malaysian Federal Court in Majilis Perbandaran Ampang Jaya, ${ }^{47}$ better known as The Highland Towers case. In this case, there was continuous rainfall for ten days. It led to the collapse of Block 1 of Highland Towers due to landslide caused primarily by water that emanated from a damaged pipe culvert and inadequate and unattended drains on the fifth defendant's land. Consequently it put the remaining two blocks owned by the plaintiffs in danger and made them uninhabitable. The plaintiffs claimed damages against ten defendants. The court allowed the plaintiff's claim against seven defendants who included the developer, architect, engineer and local authority. Holding the defendants liable for pure economic loss in the light of his own observations in Dr. Abdul Hamid Abdul Rashid, ${ }^{48}$ James Foong J applied the Donoghue Principle without any regard for limitations recognized in Murphy. In relation to the fourth defendant, the local authority, the learned judge was of the view that 'there is an ample evidence to show that MPAJ [the local authority] was required to provide a proper drainage system to be implemented on the hill slope before and during the construction of the Highland Towers apartment blocks. Accordingly he was of the view that the local authority owed a duty of

\begin{tabular}{ll}
\hline 46 & Ibid. \\
47 & Supra n 4. \\
48 & Supra n 3.
\end{tabular}


care and had breached its duty of care. However, the judge was of the view that the defendant was protected from liability by virtue of section 95(2) ${ }^{49}$ of the Street, Drainage and Building Act 1974 . He felt the immunity provided under the said section was wide enough to embrace the alleged danger created by MPAJ and/or its predecessor in diverting the East stream. ${ }^{50}$ The plaintiffs appealed against this judgment before the Court of Appeal. ${ }^{51}$ Allowing the appeal, the Court of Appeal was of the view that the local authority has created a danger by requiring or approving the diversion of the east stream on the hill slope behind Highland Towers. So the protection under section 95(2) cannot be allowed as that section does not give local authorities any power to act negligently. ${ }^{52}$ On appeal, the Federal Court restored the judgment of the High Court in relation to non-liability of the local authority. While all the judges of the Federal Court were unanimous on the pre-collapse non-liability of the defendant local authority, they were divided in relation to post-collapse liability. In giving the judgment of majority of the Federal Court, Abdul Hamid Mohamad FCJ (Arifin Zakaria FCJ concurring) held the local authority not liable even for such economic loss. In order to put his viewpoint in

$49 \quad$ S. 95 (2) reads:. The State Authority, local authority and any public officer or employee of the local authority shall not be subject to any action, claim, liability or demand whatsoever arising out of any building or other works carried out in accordance with the provision of this Act or any by-laws made thereunder or by reason of the fact that such building works or plans thereof are subject to inspection and approval by the State Authority, local authority or such public officer or employee of the State Authority or the local authority and nothing in this Act or any by-laws made thereunder shall make it obligatory for the State Authority or the local authority to inspect any building, building works or materials or the site of any proposed building to ascertain that the provisions of this Act or any by-laws made thereunder are complied with or that plans, certificates and notices submitted to him are accurate.

50 Supra 4 at p. 403.

$51 \quad$ Arab - Malaysian Finance Arab - Malaysian Finance Bhd v Steven Phoa Cheng Loon [2003] 1 MLJ 567.

$52 \quad$ Supran 4 at p. 404. 
proper perspective, he referred to s 3(1) of the Civil Law Act $1956^{53}$ and then referred to the following comment of Hashim Yeop Sani CJ (Malaya) in Chung Khiaw Bank Ltd: ${ }^{54}$

"Section 3 of the Civil Law Act 1956 directs the courts to apply the common law of England only so far as the circumstances permit and save where no provision has been made by statute law. The development of the common law after 7 April 1956 (for the States of Malaya) is entirely in the hands of the courts of this country. We cannot just accept the development of the common law in England." ${ }^{5}$

The learned judge admitted that in the instant appeal, the court was dealing with a situation where no statutory provisions have been s. 3(1) of the Civil Law Act 1956 provides:

Save so far as other provision has been made or may hereafter be made by any written law in force in Malaysia, the Court shall:

(a) in West Malaysia or any part thereof, apply the common law of England and the rules of equity as administered in England on the 7th day of April 1956;

(b) in Sabah, apply the common law of England and the rules of equity, together with statutes of general application, as administered or in force in England on the 1st day of December 1951;

(c) in Sarawak, apply the common law of England and the rules of equity, together with statutes of general application, as administered or in force in England on the 12th day of December 1949, subject however to subsection (3)(ii):

Provided always that the said common law, rules of equity and statutes of general application shall be applied so far only as the circumstances of the States of Malaysia and their respective inhabitants permit and subject to such qualifications as local circumstances render necessary. Chung Khiaw Bank Ltd v Hotel Rasa Sayang Sdn Bhd [1990] 1 MLJ 356.

$55 \quad$ Supra $\mathrm{n} 4$ at pp. 414-415; See also Government of Malaysia v Lim Kit Siang [1988] 2 MLJ 12. 
made. ${ }^{56}$ However, he found refuge in the Privy Council decision in Jamil bin Harun $^{57}$ wherein Lord Scarman observed that:

"It is for the courts of Malaysia to decide, subject always to the statute law of the Federation, whether to follow English case law. Modern English authorities may be persuasive, but are not binding. In determining whether to accept their guidance, the courts will have regard to the circumstances of the states of Malaysia and will be careful to apply them only to the extent that the written law permits and no further than in their view it is just to do so.”

The learned judge further substantiated his viewpoint by referring to an article by Professor LG Green ${ }^{58}$ wherein the author was of the view that section 3 of the Civil Law Act 1956 is out of date and contrary to national prestige.${ }^{59}$ Finally, the arrived conclusion of the learned judge was that:

We cannot just accept the development of the common law of England. ${ }^{60}$ We have to direct our mind to the 'local circumstances' or 'local inhabitants.' ${ }^{61}$

After delving into section 3 of the Civil Law Act 1956 extensively, the learned judge focused on the post-collapse liability of MPAJ. 'The self-posed a question: Does the failure or delay on the part of MPAJ to come up with and implement a master drainage plan in an effort to stabilize the Arab Malaysian land amount to actionable negligence against a public authority? ${ }^{62}$ In response to this question, the learned judge referred to the above quoted cases and his own judgment in Nepline Sdn Bhd $v$

\footnotetext{
$56 \quad$ Ibid. at p. 415.

$57 \quad$ Jamil bin Harun v Yang Kamsiah [1984] 1 MLJ 217.

58 LC Green, "Filling Lacunae in the Law,” [1963] MLJ xxviii.

$59 \quad$ Supra 4 at p. 415.

$60 \quad$ Chung Khiaw Bank Ltd v Hotel Rasa Sayang Sdn Bhd [1990] 1 MLJ 356.

61 Syarikat Batu Sinar Sdn Bhd v UMBC Finance Bhd [1990] 3 MLJ 468.

62 Supra 4 at p. 417.
} 
Jones Lang Wooten ${ }^{63}$ wherein he had allowed damages to the plaintiff tenant against the defendants, a firm of registered real estate agents and chartered valuer for failure to disclose the fact that the premises was subject to foreclosure proceedings then pending in court. He had used the 'local circumstances' theory in that case. Now, commenting again on section 3(1) of the Civil Law Act 1956, he observed that:

Pure economic loss cases in Malaysia have to be decided in the light of section 3(1) of Civil Law Act 1956 which emphasizes on local circumstances. However, I shall not venture to say where the line should be drawn. It may be said that this will lead to uncertainty in the law. The answer to that is that this whole area of common area of law itself is fraught with uncertainty. ${ }^{64}$

After detailing out his approach to section 3 of the Civil Law Act1956, the learned judge said that the question is whether it is fair, just and reasonable to impose a liability on MPAJ, a local authority, for pure economic loss to the plaintiffs for its failure (so far) to come up with and implement the promised drainage master plan or to stabilize the hill slop to ensure that no accident of the kind that caused the collapse of Block 1 would occur to Blocks 2 and 3. Answering negatively, the learned judge observed that:

"A local council is established with a host of duties to perform, from providing and maintaining recreational areas and collecting garbage to providing public transport, homes for the squatters, temporary homes in case of disasters, natural or otherwise, and so on. Indeed, the list is endless. The expectations of residents are even more. These are public duties to all residents or ratepayers within the council's geographical limit. To finance all their activities, local authorities depend mainly on assessment rates and fees for licences. In a democracy as in Malaysia and the kind of attitude of 
the people, we know too well how difficult it is to increase the rates or the fees even by a few percent. With limited resources and manpower, even if it tries its best (and generally speaking, I say they do) to provide the infrastructure and services, it will not satisfy everybody. People's demands far outweigh their contributions. When services are provided or as a result of infrastructural improvements, the value of their properties goes up, as usually happen, it is taken for granted, as their rights, their good fortune or business acumen. Then there is the attitude of the public from littering and vandalism to resorting to irresponsible means in order to maximise profits, as we see in the facts of this case as narrated by the learned High Court Judge."

Elaborating further, the learned judge continued his observations:

"With limited resources and manpower local councils would have to have their priorities. In my view, the provision of basic necessities for the general public has priority over compensation for pure economic loss of some individuals who are clearly better off than the majority of the residents in the local council area. Indeed, the large sum required to pay for the economic loss, even if a local council has the means to pay, will certainly deplete whatever resources a local council has for the provision of basic services and infrastructure. Projects will stall. More claims for economic loss will follow. There may be situations where a local council, which may only be minimally negligent, may be held to be a joint tortfeasor with other tortfeasors, which may include irresponsible developers, contractors and professionals. There is no way to execute the judgments against them. Out of necessity or for convenience, the judgment for the full amount may be enforced against the local council. The local council may go bust. Even if it does not, is it fair, just and reasonable that the taxpayers' money be utilized 
to pay for the "debts" of such people? In my view, the answer is "No"." 65

However, Steven Shim CJ (Sabah \& Sarawak) in his dissenting judgment held the local authority liable for post-collapse economic loss. After going through the legal stand on the issue in England, Australia, New Zealand and Singapore, the learned CJ observed:

"The Court of Appeal in the instant case is correct in adopting the view expressed by Lord Oliver in Murphy $v$ Brentwood that the critical question is not the nature of the damage itself, whether physical or pecuniary, but whether the scope of the duty of care in the circumstances of the case is such as to embrace damage of the kind which the plaintiff claims to have sustained. The decision in Murphy involves...the application of the Caparo test which takes into account the elements of foreseeability, proximity and the additional requirements of justice, fairness and reasonableness. ${ }^{\prime 66}$

The learned judge further disagreed with the Court of Appeal observation that the respondent's only recourse against MPAJ lay in the area of public law by way of judicial review. While holding the defendants liable, he observed:

“The failure by MPAJ to formulate and implement the master drainage plan had resulted in damages incurred by the respondents who had to evacuate their apartments in Block 2 and 3. The elements of foreseeability and proximity are clearly discernible from the established facts. Moreover, I do not think it would be in the public interest that a local authority such as MPAJ should be allowed to disclaim liability for negligence committed beyond the expansive shelter of s 95(2) or other relevant 
provisions of Act $133^{67}$ nor it would be fair, just and reasonable to deprive the respondents of their rightful claims under the law." 68

The court was further of the view that 'the respondent's claim for negligence by way of writ action is perfectly proper in law. ${ }^{69}$ Despite impressive observations by the learned judge in his dissenting opinion, the fact remains that judicially it is now certain and definite that in future a local authority in Malaysia cannot be held liable for any economic loss resulting from defective buildings.

\section{CONCLUSIONS AND SUGGESTION}

It is evident from the above discussion that there has never been consistency and simplicity in relation to the judicial approach regarding pure economic loss occasioned on account of defective buildings. The judicial responses in many jurisdictions have revolved during the last thirtyfive years from non-liability to liability to non-liability to liability to nonliability. England represents one of those countries where defective buildings economic loss cannot be claimed under tort law any more. However, it seems the approach adopted by the Malaysian judiciary is realistic and practical. Definitely, we should not have any hard and fast rule in relation to allowance of economic loss suffered on account of defective buildings. If in Lim Teck Kong, the engineer was held liable, there is justification derived from the 'just, fair and reasonable' principle. Non-liability would have meant the non-availability of legal a remedy to victims against errant builders, architects, engineers and related personnel who are found to have erred. ${ }^{70}$ Likewise, holding the local authority liable in Majlis Perbandaran Ampang Jaya would have also violated the just, fair and reasonable principle because a local authority has a host of duties and responsibilities and with limited resources and manpower, local

\footnotetext{
$67 \quad$ Street, Drainage and Building Act 1974.

$68 \quad$ Supra n 4 at p. 412.

69 Ibid.

$70 \quad$ Supra n 3, Para 31.
} 
authorities need to have their priorities. ${ }^{71}$ The latest two decisions, thus, indicate that the Malaysian judiciary is doing its best to balance the just interests of the parties with regard to economic loss suffered on account of defective buildings and is no more swayed by the approaches adopted in developed countries like United Kingdom and Australia. The suggestion by some judges ${ }^{72}$ and lawyers ${ }^{73}$ that the Parliaments should enact laws on the issue of economic loss seems unrealistic because the circumstances under which a person suffers such loss nowadays are unlimited and sometimes beyond human perception. There is a need to allow the judiciary to play its unfettered role in addressing such issues in the light of foreseeability, proximity and 'just, fair and reasonable' elements of duty of care.

$71 \quad$ Supra 4 at p. 423.

72 Woolcock Street Investment Pty Ltd. V CDG Pty Ltd (2004) 204 ALR 522 at p. 580.

73 Dominic J, \& Firoz Hussein, "Public Policy: Onus on Parliament to Remove Uncertainty,” New Straits Times, March 26, 2006, p. 23. 